\title{
THE ANALYSIS OF HEAVY METAL POLLUTANTS EMITTED BY RAILWAY TRANSPORT
}

\author{
Rasa VAIŠKŪNAITE் ${ }^{\star}$, Vilma JASIŪNIENE ${ }^{2}$ \\ ${ }^{1}$ Dept of Environmental Protection and Water Engineering, Vilnius Gediminas Technical University, Lithuania \\ ${ }^{2}$ Road Research Institute, Vilnius Gediminas Technical University, Lithuania
}

Received 27 December 2019; revised 5 April 2020, 10 May 2020; accepted 12 May 2020

\begin{abstract}
Recently, concern for a rapid increase in heavy metal pollutants released by railway transport has been expressed. Most of pollutant emissions from combustion processes are related to fuel consumption in the internal combustion engines of traction rolling stock. The main pollutants released into the environment cover particulate matter, volatile non-methane organic compounds, sulphur dioxide and nitrogen oxides. In this way, it is likely that the biggest polluters of the environment are traction units with internal combustion engines. However, other types of pollution are possible, where polluters can be not only traction rolling stock with the internal combustion engines, but also electric locomotive. For example, when due to friction of metals and deterioration of rolling stock wheels, heavy metals such as aerosols are released into the atmosphere, soil, surface and ground water, etc. and severely pollute the railway environment. Along with an increase in the electrification of railways, local environmental pollution is likely to be increased in the future. High pollution by heavy metals can also occur near the track storing creosote-impregnated wooden railway sleepers. Having analysed railway transport intensity and in order to assess pollution level, the stations of three major cities of Lithuania (Vilnius, Kaunas and Klaipeda) were selected to investigate heavy metal pollutants (lead ( $\mathrm{Pb})$, cadmium $(\mathrm{Cd})$, zinc $(\mathrm{Zn})$ ) acting as the most toxic and widespread elements. The highest concentrations of $\mathrm{Pb}$ (up to $50 \mathrm{mg} / \mathrm{kg}$ ) were found at a distance of $5.0 \mathrm{~m}$ from railway sleepers in the upper (up to $10 \mathrm{~cm}$ ) soil layer at Vilnius Railway Station. A comparison of the results of the investigated soil across the tested stations showed that Klaipeda Railway Station was the area most polluted with Cd. The highest concentrations of Cd (up to $1.5 \ldots 1.8 \mathrm{mg} / \mathrm{kg}$ ) were established at a varying distance of $5 \ldots 10 \mathrm{~m}$ from the sleepers in the upper (up to $10 \mathrm{~cm}$ ) soil layer of light loam. Among the investigated stations, the lowest pollution by heavy metals, including $\mathrm{Zn}$, was found at Kaunas Railway Station where sandy loam dominated. A comparison of heavy metal pollutants deposited on the intact used and rotten wooden railway sleepers disclosed that the latter were more heavily contaminated with heavy metals and made from 8 to $13 \mathrm{mg} / \mathrm{kg}$ for $\mathrm{Pb}$, from 0.3 to $1.2 \mathrm{mg} / \mathrm{kg}$ for $\mathrm{Cd}$, from 13.8 to $66 \mathrm{mg} / \mathrm{kg}$ for $\mathrm{Zn}$.
\end{abstract}

Keywords: railway transport, pollution, wooden railway sleepers, environmental protection, soil pollution, heavy metals, lead, cadmium, zinc.

\section{Notations of chemical elements}

$\begin{array}{ll}\mathrm{Al} \text { - aluminium; } & \mathrm{Mn} \text { - manganese; } \\ \mathrm{As} \text { - arsenic; } & \mathrm{Mo} \text { - molybdenum; } \\ \mathrm{Ba} \text { - barium; } & \mathrm{Na} \text { - sodium; } \\ \mathrm{Ca} \text { - calcium; } & \mathrm{Ni} \text { - nickel; } \\ \mathrm{Cd} \text { - cadmium; } & \mathrm{Pb} \text { - lead; } \\ \mathrm{Co} \text { - cobalt; } & \mathrm{Pt} \text { - platinum; } \\ \mathrm{Cr} \text { - chromium; } & \mathrm{Sb} \text { - antimony; } \\ \mathrm{Cu} \text { - copper; } & \mathrm{Se} \text { - selenium; } \\ \mathrm{Fe} \text { - iron; } & \mathrm{V} \text { - vanadium; } \\ \mathrm{Hg} \text { - mercury; } & \mathrm{Zn} \text { - zinc. } \\ \mathrm{K} \text { - potassium; } & \end{array}$

\section{Introduction}

Railway transport appears as one of the major polluters of the environment. Most of pollutant emissions from combustion processes are related to fuel consumption in the internal combustion engines of traction rolling stock. The main pollutants released into the environment cover particulate matter, volatile non-methane organic compounds, sulphur dioxide and nitrogen oxides. In this way, it is likely that the biggest polluters of the environment are traction units with internal combustion engines. However, other types of pollution are possible, where polluters can be not only traction rolling stock with the internal combustion engines, but also electric locomotive. For example,

${ }^{*}$ Corresponding author. E-mail: rasa.vaiskunaite@vgtu.lt 
when due to friction of metals and deterioration of rolling stock wheels, heavy metals such as aerosols are released into the atmosphere, soil, surface and ground water, etc. and severely pollute the railway environment. Along with an increase in the electrification of railways, local environmental pollution is likely to be increased in the future. High pollution by heavy metals can also occur near the track storing creosote-impregnated wooden railway sleepers. Thus, the concentrations of heavy metals $(\mathrm{Pb}, \mathrm{Cd}, \mathrm{Cu}$, $\mathrm{Zn}, \mathrm{Fe}, \mathrm{Cr}, \mathrm{Hg}$, etc.) in the soil can be several times higher than those in the clean control sites outside the study. The pollutants accumulated in the soil can alter its $\mathrm{pH}$ thus destroying its natural chemical, physical and biological balance. Physiochemical changes in the environment may lead to the redistribution of the accumulated pollutants on the soil surface. A part of them migrate to deeper soil horizons. When entered groundwater, the pollutants tend to accumulate in the sludge of shaft wells (Christoforidis, Stamatis 2009; Bai et al. 2011; Hasselbach et al. 2005; Helmreich et al. 2010; Šeda et al. 2017; Paschke et al. 2000; Wierzbicka et al. 2015; Zhang et al. 2013).

The elements weighing more than $5 \mathrm{~g} / 1 \mathrm{~cm}^{3}$ are commonly referred to as heavy metals. As for biological classification, the elements with an atomic weight greater than 40 tend to be named as heavy metals. Some of these elements, including $\mathrm{Fe}, \mathrm{Co}, \mathrm{Zn}, \mathrm{Cu}, \mathrm{Mn}$, etc. are simply given the name of microelements that are essential for living organisms. However, high concentrations are harmful to living organisms. 38 heavy metals are counted in nature but not all are unconditionally classified as toxic (Chen et al. 2014).

Element toxicity rises with an increase in atomic weight. Any element, subject to its concentration and form of a chemical compound, can become toxic. Heavy metals can cause endemic diseases related to a specific element, lead to growth and developmental abnormalities and weaken the immunity system. Some of more dangerous heavy metals embrace $\mathrm{Cd}, \mathrm{Pb}, \mathrm{Zn}$, etc. (Chen et al. 2014).

There are no natural processes that destroy metals at the rate they have been artificially introduced into ecosystems. Some scientists, however, still believe that metals are slowly eliminated by leaching under erosion and deflation thus entering plants. Lysimetric research on the arable land of turf sandy loam and heavy clay loam demonstrated that the soil polluted with heavy metals $(\mathrm{Cd}, \mathrm{Zn}$ and $\mathrm{Pb})$ decontaminated very slowly during natural processes. It takes about 500 years for $\mathrm{Zn}, 500$ for $\mathrm{Cd}$ and 1100 for $\mathrm{Pb}$ (Zhang et al. 2012) for the half-life of being eliminated from the soil (halving its initial concentration).

Since the late 1990s, some pollution investigations have found that air and soil alongside railway had higher heavy metal levels than control sites (Chen et al. 2014; Lorenzo et al. 2006). Chen et al. (2014) revealed that friction processes between wheel sets and rails during railway transportation make railways released heavy metals including $\mathrm{Zn}, \mathrm{Cd}, \mathrm{Pb}$ and other into the environment. With regard to the soil heavy metal pollution along railways, recent studies are primarily focus on the heavy metal pollution levels at different function areas (Chen et al. 2014), the concentration variation of soil heavy metals with the distance from track (Lorenzo et al. 2006) and the influence of environmental factors (topography, temperature and $\mathrm{pH}$ ) on the distribution pattern of heavy metals sleepers (Liu et al. 2009; Zhang et al. 2012; Chen et al. 2010; Baumhardt et al. 2015; Blake, Goulding 2002; Blok, 2005; Dai et al. 2004; Fakayode, Olu-Owolabi 2003; Khan et al. 2011a; Li et al. 2007; Lee et al. 2009; Liu et al. 2009; Ma et al. 2009; Malawska, Wiołkomirski 2001; Morra et al. 2009; Plakhotnik et al. 2005; Saeedi et al. 2009; Stojic et al. 2017; Wiłkomirski et al. 2012).

Research has found that road transport affects levels of numerous heavy metals, including $\mathrm{Pb}, \mathrm{Cd}, \mathrm{Cu}, \mathrm{Zn}, \mathrm{Cr}, \mathrm{Ni}$, $\mathrm{Fe}, \mathrm{Mn}, \mathrm{Al}, \mathrm{Co}, \mathrm{V}, \mathrm{Sb}, \mathrm{Ba}, \mathrm{Pt}, \mathrm{Mo}, \mathrm{Hg}$, Se and As. Chinese scientists have only examined the relationship between railways and heavy metals for a limited number of elements, i.e., $\mathrm{Ni}, \mathrm{Pb}, \mathrm{Mn}, \mathrm{Cr}, \mathrm{Zn}, \mathrm{Cu}$ and $\mathrm{Cd}$. Scientists have directed greater attention to the soil environment near railways. Their research has shown that railway transportation can affect the surrounding environment, especially in urban areas. With respect to the soil environment along railways, recent studies have primarily shown: the differences of soil heavy metals across different sites, the horizontal distribution of soil heavy metals, and the influence of terrains on soil heavy metal distribution (Liu et al. 2009; Zhang et al. 2012).

For example, the studied by Chinese scientists Qinghai-Tibet railway provides favourable conditions for exploring the effects of railways on soil heavy metal enrichment. These results indicate that railway transport has a significant effect on the concentration of $\mathrm{Zn}, \mathrm{Cd}$ and $\mathrm{Pb}$ in the soil, with levels of enrichment ranging from no pollution to significant pollution. The affected area was within $20 \mathrm{~m}$ of the railway. The soil at Delingha was the most contaminated soil with heavy metals, and the enrichment level of $\mathrm{Cd}$ in the soil was the highest along the Qinghai-Tibet railway. The horizontal distributions of the three heavy metals present different characteristics at different sampling sites, which may be due to discrepancies in terrain and vegetation types. Alkaline soils and guardrails along the railway might reduce the effect of soil pollution on local people and animals (Zhang et al. 2012).

The study other Chinese scientists investigated the effects of railway transportation on the enrichment of heavy metals in the artificial soil on railway cut slopes near Suining Railway Station (Sichuan Province, China). The results showed that the cut slopes were polluted by $\mathrm{Cd}$ and $\mathrm{Pb}$. $\mathrm{Cd}$ exhibited remarkably higher levels compared to the results of other studies. Consequently, Cd contamination in the soils at the study sites was noteworthy. The contaminate levels increased with the operation time of the railway lines. $\mathrm{Cd}$ and $\mathrm{Pb}$ showed a moderate enrichment in the soils and all sampling locations showed considerable ecological risks. Railway traffic made a great contribution to elevated $\mathrm{Pb}$ and $\mathrm{Cd}$ in railway-side soils, but little influence on $\mathrm{Cr}, \mathrm{Cu}$ and $\mathrm{Fe}$ (Chen et al. 2014). 
The study of Czech scientists revealed that the wooden railway ties could be a source of $\mathrm{Hg}$ and $\mathrm{Cu}$ in soils near older railway s since their wooden ties were impregnated with $\mathrm{Hg}$ and $\mathrm{Cu}$ compounds. Wooden railway ties are considered as a potential source of $\mathrm{Hg}$ because of impregnation with antifungal $\mathrm{Hg}$ compounds. The level of $\mathrm{Cu}$ concentration in soil depends on the distance of nearby railway as trains release $\mathrm{Cu}$ into the environment as well. However, the relatively fast decrease in concentrations of individual contaminants with increasing distance from the railway indicates that the safe distance, e.g. for agricultural production, is approximately $10 \mathrm{~m}$ from the source of pollution (Šeda et al. 2017).

Recent research by Serbian scientists confirms that that surface soil $(0 \ldots 10 \mathrm{~cm})$ samples from 60 sampling sites along the length of railway tracks on the territory of Srem (the western part of the Autonomous Province of Vojvodina, itself part of Serbia) were collected and analysed for ten heavy metals in order to see how the distance from the railway affects the concentration of some organic and inorganic pollutants in the soil. According to results of these studies $\mathrm{Cu}, \mathrm{Co}, \mathrm{Zn}$ and $\mathrm{Ni}$ were the most ubiquitous heavy metals in the area near railway. Based on these results, it can be said that railway transport is a potential source of these heavy metals. Despite the fact that in most of the samples pollutants do not exceed acceptable levels of pollution (except in the case of $\mathrm{Co}$ and $\mathrm{Ni}$ ), there are indications that the current amount of inorganic pollutants is a potential threat to the environment, so routinely monitoring of soil in the area around the railway track and railway stations is justified (Stojic et al. 2017).

The purpose of this study is to assess heavy metal contamination levels $(\mathrm{Pb}, \mathrm{Cd}$, and $\mathrm{Zn})$ in the stations of three major cities of Lithuania (Vilnius, Kaunas and Klaipeda) and to investigate the impact of railway operation on the enrichment of heavy metals $\mathrm{n}$ the intact used and rotten wooden railway.

\section{Methodology}

Having analysed railway transport intensity and in order to assess heavy metal pollutants - $\mathrm{Pb}, \mathrm{Cd}, \mathrm{Zn}-$ the stations of 3 major cities of Lithuania (Vilnius, Kaunas and Klaipeda) were selected (Figure 1).

Each soil sample was collected on the "envelope" basis from different points across the area of $100 \mathrm{~m}^{2}(10 \times 10 \mathrm{~m})$. Thus, the samples were taken at the distances of $1,5,10,15$ and $25 \mathrm{~m}$ from the sleepers arranged in different soil layers (upper layer of up to $10 \mathrm{~cm}$ deep) and deeper $(10 \ldots 20$ and $20 \ldots 40 \mathrm{~cm}$ ). Soil samples were obtained using standardized equipment with reference to standards: LST ISO 10381-1:2005, LST ISO 10381-2:2005, LST ISO 103813:2003, LST ISO 10381-4:2006, LST ISO 10381-5:2007. The collected samples (500 $\mathrm{g}$ in weight) were analysed on

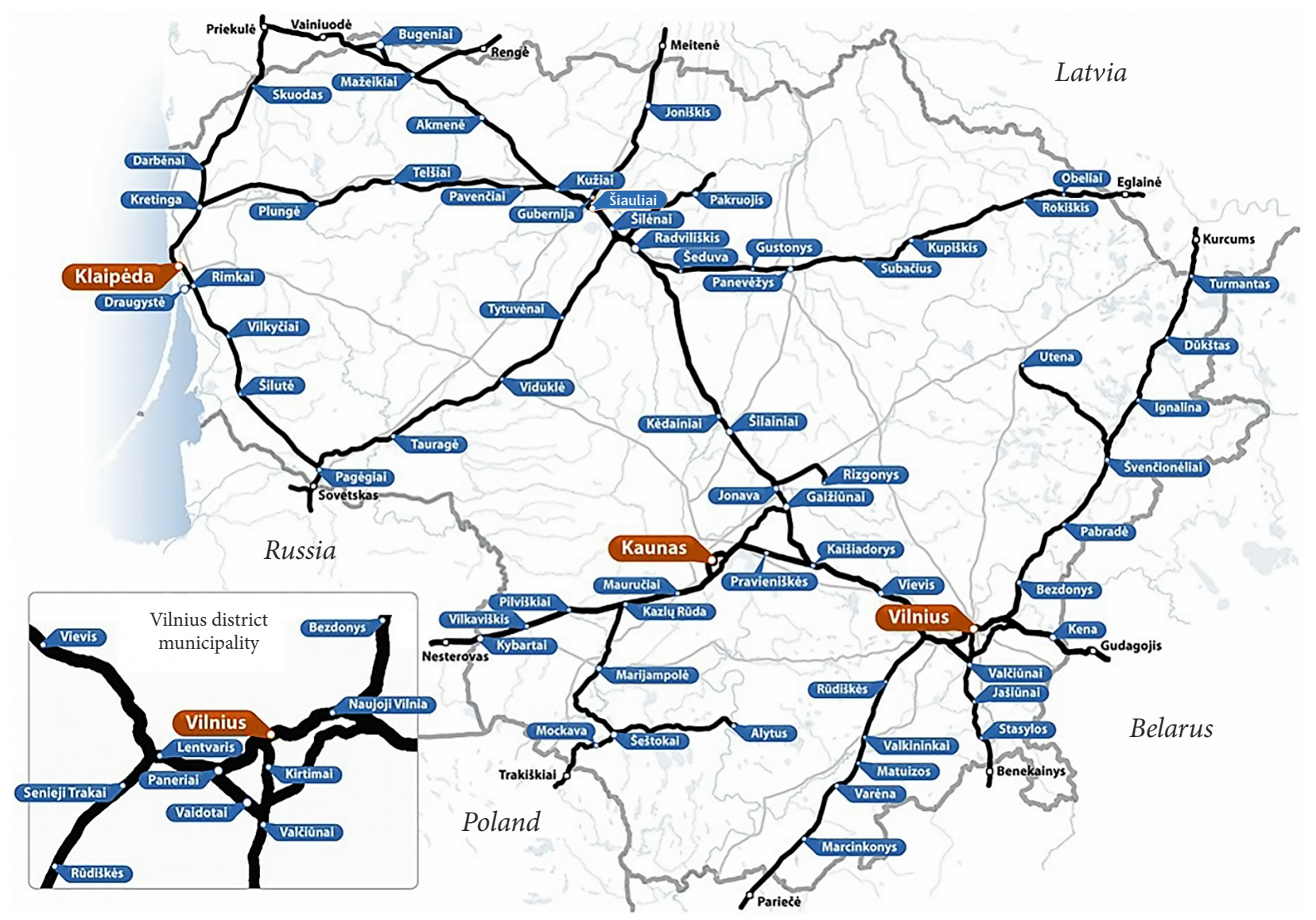

Figure 1. The stations of three major cities of Lithuania (Vilnius, Kaunas and Klaipeda) 
the analytical basis. Heavy metals $(\mathrm{Pb}, \mathrm{Cd})$ were investigated according to standard LST CEN/TS 16172:2013 applying graphite furnace atomic absorption spectrometry. Heavy metal $(\mathrm{Zn})$ analysis was performed following standard LST CEN/TS 16188:2012 employing flame atomic absorption spectrometry.

The carried out research involved the concentrations of heavy metals, including $\mathrm{Pb}, \mathrm{Cd}$ and $\mathrm{Zn}$, present in wooden railway sleepers. The samples were taken from the end of the intact used sleeper, the upper impregnated layer and the rotten sleeper. In order to assess the contamination of wooden railway sleepers, a new methodology for their collection and research has been adapted. The samples were collected from three railway stations (Vilnius, Kaunas and Klaipeda) and submitted for analytical analysis according to the aforementioned methods of atomic absorption spectrometry (Vilniškis, Vaiškūnaitè 2018). The novelty of this methodology consisted of complex studies of heavy metals $(\mathrm{Pb}, \mathrm{Cd}, \mathrm{Zn})$ distribution in different soil profiles near railway stations, i.e. studies of soil morphological properties, studies of organic matter content and granulometric composition, studies and assessment of soil upper horizon contamination with heavy metals, studies of heavy metals mobile exchange distribution of concentrations in different soil profiles.

Based on Lithuanian Hygiene Norm on Threshold Limit Value of Hazardous Substances in the Soil (HN 60:2015), the specified threshold limit value of hazardous substances $R V_{p}$ was established. This is the limit value of a hazardous chemical calculated according to the soil characteristics of a specific area.

Heavy metal pollutants found in the soil are determined with reference to $R V_{p}$ equal to:

$$
R V_{p}=R V \cdot \frac{A+B+M_{\%}+C \cdot O M_{\%}}{A+B \cdot 10+C+3},
$$

where: $R V_{p}$ - specified threshold limit value of hazardous substances in the soil; $R V$ - threshold limit value of hazardous substances in the soil; $M_{\%}$ - content [\%] of clay particles (less than $0.002 \mathrm{~mm}$ in diameter) in the examined soil. In the cases when the established content of clay soil particles exceeds $50 \%$ or is less than $10 \%$, the values of 50 or $10 \%$ respectively shall be inserted in the formula; $O M_{\%}$ - content [\%] of soil organic matter. In the cases when the established content of soil organic matter exceeds $10 \%$ or is less than $3 \%$, the values of 10 or $3 \%$ respectively shall be inserted in the formula; $A, B, C$ - coefficients the values of which are subject to heavy metals (Table).

Table. The coefficients used for establishing the specified threshold limit values $R V_{p}$ of the investigated heavy metals

(HN 60:2015)

\begin{tabular}{|l|c|c|c|}
\hline \multirow{2}{*}{$\begin{array}{c}\text { Heavy } \\
\text { metal }\end{array}$} & \multicolumn{3}{|c|}{$\begin{array}{c}\text { Coefficients the values of which are subject } \\
\text { to heavy metals }\end{array}$} \\
\cline { 2 - 4 } & $\mathrm{A}$ & $\mathrm{B}$ & $\mathrm{C}$ \\
\hline $\mathrm{Pb}$ & 50 & 1.0 & 1.0 \\
\hline $\mathrm{Cd}$ & 0.4 & 0.007 & 0.021 \\
\hline $\mathrm{Zn}$ & 50 & 3.0 & 1.5 \\
\hline
\end{tabular}

The results of the conducted research were evaluated applying mathematical-statistical methods using the $M i$ crosoft Excel program. The accuracy of the averages of the obtained results was statistically evaluated from five replicates. Unreliable results were retested.

\section{Research results}

\subsection{Determining $\mathrm{Pb}$}

$\mathrm{Pb}$ concentrations in the investigated soil of Vilnius, Kaunas and Klaipeda railway stations did not exceed the specified threshold limit value of hazardous substances $(80 \mathrm{mg} / \mathrm{kg})$. The highest concentrations of $\mathrm{Pb}$ (up to $50 \mathrm{mg} / \mathrm{kg}$ ) in the upper (up to $10 \mathrm{~cm}$ ) soil layer were found at a distance of $5.0 \mathrm{~m}$ from railway sleepers at Vilnius Railway Station (Figure 2). As for the application of statistical methods, recent research has demonstrated extremely high approximation coefficients $\left(R^{2}\right)$ (up to 0.99 ). Such amounts of $\mathrm{Pb}$ were significantly affected by the content of physical clay particles, fine dispersion fraction (particles $<0.002 \mathrm{~mm}$ ), the origin of soil rock, the content of organic matter present in the soil and its acidity $(\mathrm{pH})$. Fine sand $(0.25 \ldots 0.05 \mathrm{~mm})$ fraction predominated in sandy and clay loam soils in the area of Kaunas Railway Station, and $\mathrm{Pb}$ concentration was 1.1 times less than that in the soil of heavier granulometric composition, that of limnoglacial origin (coarse dust fraction of $0.005 \ldots 0.01 \mathrm{~mm}$ in diameter was prevailing) and that in the soil of higher organic matter content and lower $\mathrm{pH}$ (Vilnius Railway Station). As for deeper soil layers $(10 \ldots 20$ and $20 \ldots 40 \mathrm{~cm})$, the concentrations of the above mentioned pollutant were evenly distributed within the limits of $10 \ldots 20$ and $8 \ldots 12 \mathrm{mg} / \mathrm{kg}$ respectively, which was confirmed by statistical analysis $\left(R^{2}=0.95\right)$. A comparison of the findings of $\mathrm{Pb}$ investigated at all railway stations demonstrated the remaining similar trend. The highest concentrations of $\mathrm{Pb}$ (up to $30 \ldots 60 \mathrm{mg} / \mathrm{kg}$ ) in the upper (up to $10 \mathrm{~cm}$ ) soil layer was found at a distance of $5 \ldots 10 \mathrm{~m}$ from railway sleepers at Klaipeda and Kaunas railway stations. Correspondingly, minor variations in $\mathrm{Pb}$ concentrations, i.e. from 10 to $18 \mathrm{mg} / \mathrm{kg}$, were observed in the deeper soil layers $(10 \ldots 20$ and $20 \ldots 40 \mathrm{~cm})$ of the above mentioned railway stations at a distance of $10 . .25 \mathrm{~m}$ from railway sleepers. Thus, under a negative anthropogenic effect, the mobility of metals can greatly alter and natural low-activity $\mathrm{Pb}$ can even become very mobile. In terms of the amount of mobile forms, heavy metals form the following order: $\mathrm{Pb}>\mathrm{Zn}>\mathrm{Mn}>\mathrm{Co}>\mathrm{Ni}>\mathrm{Cu}>\mathrm{Cr}$ (Chen et al. 2014). The results of the study showed that $\mathrm{Pb}$ had a relatively high level of mobility on the railway, which made $25 \mathrm{~km}$ from the track. Similarly, to the data provided by other scientists (Burkhardt et al. 2008; Christoforidis, Stamatis 2009; Davis et al. 2001; Fonseca et al. 2011; Guo et al. 2012; Ho, Tai 1988; Khan et al. 2011b; Kim, K.-H., Kim, S.-H. 1999; Langmi, Watt 2003; Saeedi et al. 2012; Nabulo et al. 2006; Sansalone, Buchberger 1997; Stojic et al. 2017; Tromp et al. 2012), these figures reaffirmed that $\mathrm{Pb}$ adsorption and desorption processes in the soil as well as their distribution in the solid and liquid phases of 
the soil were highly complex and subject to a number of factors, including an anthropogenic aspect.

Complex studies of the $\mathrm{Pb}$ pollution have shown that in order to reduce the negative impact on the environment, that the safe distance from the railway stations are up to $10 \ldots 15 \mathrm{~m}$. Therefore, based on the research of the scientists, it can be stated that it is necessary not only to monitor the distribution of $\mathrm{Pb}$ in different soil profiles, but also to monitor the morphological properties of the soil, its organic matter content and granulometric composition (Stojic et al. 2017; Šeda et al. 2017; Zhang et al. 2012; Chen et al. 2014).

\subsection{Determining Cd}

A comparison of the results of the investigated soil across the tested railway stations disclosed that Klaipeda Railway Station was the most polluted with $\mathrm{Cd}$. The highest $\mathrm{Cd}$ concentrations (up to $1.5 \ldots 1.8 \mathrm{mg} / \mathrm{kg}$ ) were found in the upper (up to $10 \mathrm{~cm}$ ) soil layer at a distance of $5 \ldots 10 \mathrm{~m}$ from the railway sleepers placed in light clay loam (Figure 3 ).

Thus, the specified threshold limit value of hazardous substances $(1.5 \mathrm{mg} / \mathrm{kg})$ was exceeded. The site of technogenic pollution (10...25 $\mathrm{m}$ from the track) suffered from higher soil pollution. As for the application of statistical methods, recent research has demonstrated extremely high approximation coefficients $\left(R^{2}\right)$ (up to 0.97). The results of the conducted study showed that the effect of railway transport on the roadside soil polluted with $\mathrm{Cd}$ was significant. Due to the higher concentration of humus, clay, minerals, phosphate and carbonate ions in the soil of Klaipeda Railway Station, insoluble and inorganic Cd compounds formed. The produced heavy metal-organic compounds may be of varying durability thus ranging from semi-persistent to fragile. The persistence of $\mathrm{Cd}$ compounds with humic substances is lower than that of $\mathrm{Pb}$ or $\mathrm{Zn}$, and therefore $\mathrm{Cd}$ ions can move faster from organic complexes to the mobile state in the soil than the other metals (Chen et al. 2014). According to the mass fraction of mobile ions (as much as $56 . .70 \%$ ), the other part of Cd enters minerals (hydroxides) or migrates in the form of true solutions (Stojic et al. 2017). The migration of $\mathrm{Cd}$ ions in the soil depends on adsorption-desorption processes involving $\mathrm{Cd}$ and other heavy metals. Like those of other heavy metals, $\mathrm{Cd}$ ions are absorbed in the soil by the sorbent complex and take part in ion exchange and other processes. The soil is a complex multicomponent system embracing the adsorption and desorption of metal ions, i.e. transition to soil solution (mobile state) is a reversible process. This equilibrium depends on a number of factors such as $\mathrm{pH}$, soil sorption capacity, temperature, humidity, light, interaction with other cations, etc. (Huang et al. 2004; Koeleman et al. 1999; Kluge, Wessolek 2012; Lorenzo et al. 2006; Norrström 2005; Olajire, Ayodele 1997; Pagotto et al. 2001; Sezgin et al. 2004; Stojic et al. 2017; Wiłkomirski et al. 2011; Vitaliano 1992).

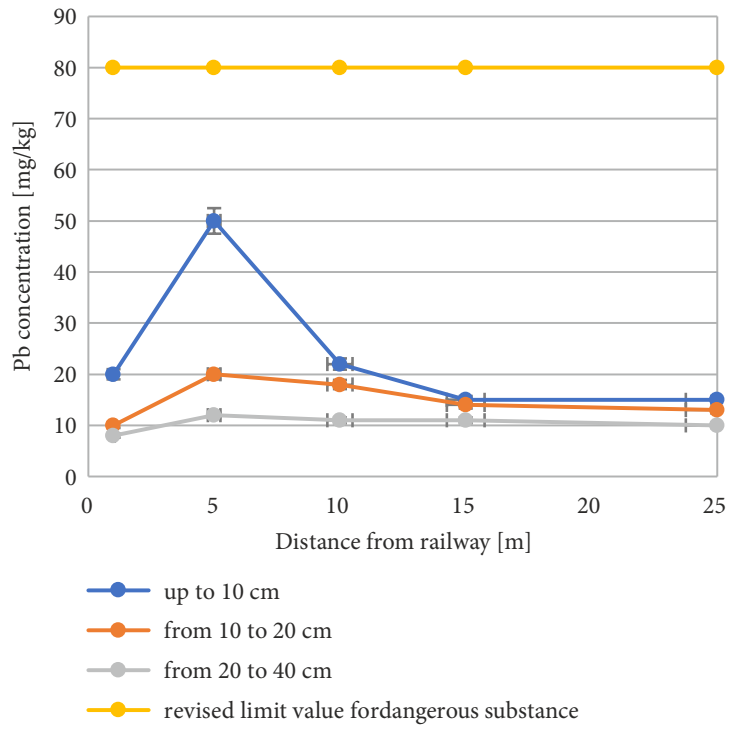

Figure 2. The influence of the distance from the railway on $\mathrm{Pb}$ concentration in the soil of Vilnius Railway Station (samples of up to $10 \mathrm{~cm}$ from the depth of $10 \ldots 40 \mathrm{~cm}$ )

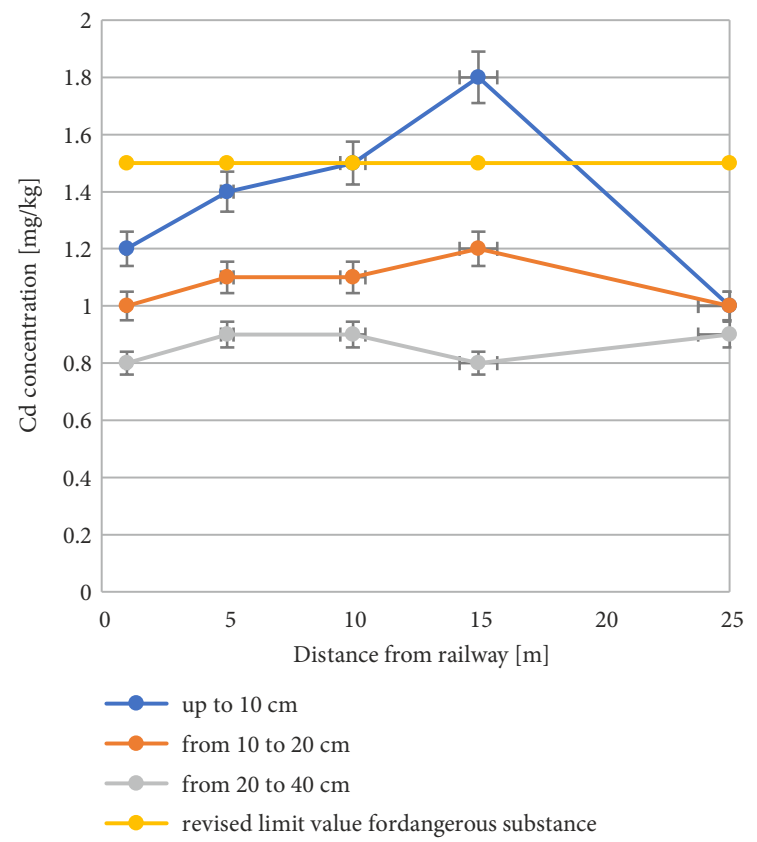

Figure 3. The influence of the distance from the railway on Cd concentration in the soil of Klaipeda Railway Station (samples of up to $10 \mathrm{~cm}$ from the depth of $10 \ldots 40 \mathrm{~cm}$ )

The conducted study documented that the content of this heavy metal in the soil was mostly subject to its granulometric composition: a growth in the amount of physical clay particles $(<0.01 \mathrm{~mm})$ resulted in a rising content of $\mathrm{Cd}$. An increasing distance from the road gradually decreased Cd concentrations from 0.8 to $1.8 \mathrm{mg} / \mathrm{kg}$. As for the deeper layers of the soil $(10 \ldots 20$ and $20 \ldots 40 \mathrm{~cm})$, $\mathrm{Cd}$ concentrations evenly distributed within the limits of $1 \ldots 1.2$ and $0.8 \ldots 0.9 \mathrm{mg} / \mathrm{kg}$ respectively, which was confirmed by statistical analysis $\left(R^{2}=0.95\right)$. Considering other railway stations situated in Vilnius and Kaunas, soil 
pollution with Cd was twice as low and distributed evenly in all soil layers, i.e. from 0.4 to $0.7 \mathrm{mg} / \mathrm{kg}$. Hence, $\mathrm{Cd}$ ions dominated in the mobile state in the soils of the latter railway stations.

Complex studies of the $\mathrm{Cd}$ pollution have shown that in order to reduce the negative impact on the environment, that the safe distance from the railway stations are up to $15 \mathrm{~m}$. Therefore, based on the research of the scientists, it can be stated that it is necessary not only to monitor the distribution of $\mathrm{Cd}$ in different soil profiles, but also to monitor the morphological properties of the soil, its granulometric composition and higher concentration of humus, clay, minerals, phosphate and carbonate ions in the soil. Complex studies have confirmed that the contaminate levels of Cd increased with the operation time of the railway lines (Stojic et al. 2017; Šeda et al. 2017; Zhang et al. 2012; Chen et al. 2014).

\subsection{Determining $\mathrm{Zn}$}

Among the investigated stations, the lowest level of pollution by heavy metals, including $\mathrm{Zn}$, was found at Kaunas Railway Station where sandy loams predominated. Maximum pollution with $\mathrm{Zn}$ (up to $130 \mathrm{mg} / \mathrm{kg}$ ) was recorded at a distance of $10 \ldots 20 \mathrm{~m}$ from railway sleepers; however, it did not exceed the specified threshold limit value of hazardous substances $(300 \mathrm{mg} / \mathrm{kg}$ ) (Figure 4).

As for the application of statistical methods, recent research has demonstrated extremely high approximation coefficients $\left(R^{2}\right)$ (up to 0.98 ). Actually, more $\mathrm{Zn}$ may have accumulated in the upper layer due to a higher content of organic material where $\mathrm{Zn}$ was more likely to accumulate. As for deeper soil layers $(10 \ldots 20$ and $20 \ldots 40 \mathrm{~cm})$,

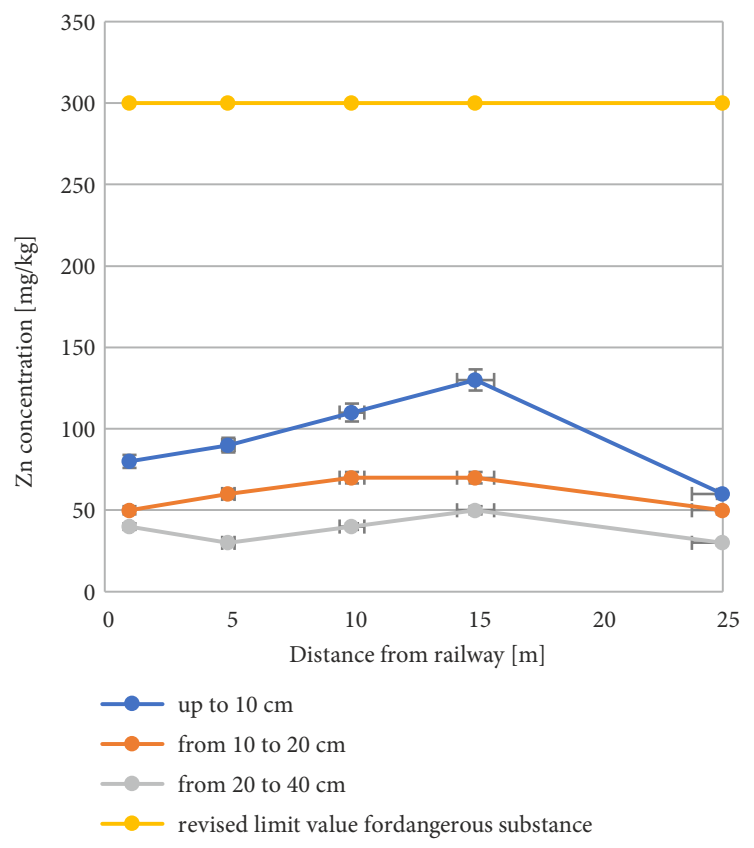

Figure 4. The influence of the distance from the railway on $\mathrm{Zn}$ concentration in the soil of Kaunas Railway Station (samples of up to $10 \mathrm{~cm}$ from the depth of $10 \ldots 40 \mathrm{~cm}$ ) the concentrations of the tested pollutant evenly distributed within the limits of $50 \ldots 70$ and $30 \ldots 50 \mathrm{mg} / \mathrm{kg}$ respectively. Organic matter is frequently flushed from the upper to the deeper layers of the soil. This fact is corroborated by other research findings (Zhang et al. 2012). For this reason, $\mathrm{Zn}$ in particular was found in considerable numbers in this layer. A comparison of the results of $\mathrm{Zn}$ tested at all investigated railway stations demonstrated the remaining similar trend. The highest concentrations of $\mathrm{Pb}$ (up to $180 \ldots 200 \mathrm{mg} / \mathrm{kg}$ ) were found in the upper (up to $10 \mathrm{~cm}$ ) soil layer at a varying distance of $10 \ldots 20 \mathrm{~m}$ from railway sleepers at Klaipeda and Vilnius railway stations. Correspondingly, fluctuations in the concentrations of $\mathrm{Pb}$ were minor and made from 50 to $78 \mathrm{mg} / \mathrm{kg}$ in the deeper soil layers $(10 \ldots 20$ and $20 \ldots 40 \mathrm{~cm})$ of the above mentioned railway stations at a distance of $10 . .25 \mathrm{~m}$ from railway sleepers. This was confirmed by statistical analysis $\left(R^{2}=0.96\right)$. It can be noted that pollution with $\mathrm{Zn}$ established in the soil at Klaipeda Railway Station was approximately twice as polluted as that of the other investigated stations where the soil of moderate granulometric composition dominated and where the solubility of $\mathrm{Zn}$ increased with a rise in the $\mathrm{pH}$ value thus forming zincates. In recent years, the soil has been adversely affected by acid rain containing sulphur, hydrochloric and nitric acids. When exposed to soil surface horizons, pollutants increase their acidity, intensify leaching alkaline biogenic cations (K, Na, $\mathrm{Ca}, \mathrm{Mn}, \mathrm{Ba}$ ), $\mathrm{Fe}, \mathrm{Al}$ and $\mathrm{Mn}$ and increase heavy metal (not only $\mathrm{Zn}$, but also $\mathrm{Cd}, \mathrm{Pb}$ and others) activity, mobility and toxicity (Stojic et al. 2017).

If the investigated heavy metals $(\mathrm{Cd}, \mathrm{Pb}, \mathrm{Zn})$ form complex compounds with humic substances, their durability is arranged as $\mathrm{Pb}>\mathrm{Zn}>\mathrm{Cd}$. In this case, the most easily absorbed $\mathrm{Pb}$ ions and the least easily absorbed $\mathrm{Cd}$ and $\mathrm{Zn}$ ions can be observed (Shi et al. 2008; Smičiklas et al. 2015; Stojić et al. 2014; Sun et al. 2010; Száková et al. 2010; Wei, Yang 2010; Zehetner et al. 2009; Vilniškis, Vaiškūnaitè 2018; Zhang et al. 2012).

Analogously performed and previously discussed $\mathrm{Pb}$ pollution studies, complex studies of the $\mathrm{Zn}$ pollution have shown that in order to reduce the negative impact on the environment, that the safe distance from the railway stations are up to $10 \ldots 15 \mathrm{~m}$. Therefore, based on the research of the scientists, it can be stated that it is necessary not only to monitor the distribution of $\mathrm{Zn}$ in different soil profiles, but also to monitor the morphological properties of the soil, its organic matter content and granulometric composition (Stojic et al. 2017; Šeda et al. 2017; Zhang et al. 2012; Chen et al. 2014).

\subsection{Concentrations of heavy metals $(\mathrm{Pb}, \mathrm{Cd}, \mathrm{Zn})$ in the intact used and rotten wooden railway sleepers}

A comparison of heavy metal pollutants found on the intact used and rotten wooden railway sleepers disclosed that the latter sleepers compared to the intact used ones, were more seriously polluted with heavy metals, which made from 8 to $13 \mathrm{mg} / \mathrm{kg}$ for $\mathrm{Pb}$, from 0.3 to $1.2 \mathrm{mg} / \mathrm{kg}$ 
for $\mathrm{Cd}$ and from 13.8 to $66 \mathrm{mg} / \mathrm{kg}$ for $\mathrm{Zn}$. The rotten sleepers contained a higher content of organic compounds involved in forming complex compounds of varying durability ranging from semi-persistent to fragile (Figures 5-7). This was confirmed by statistical analysis $\left(R^{2}=0.95\right)$. Meanwhile, for examining the contamination of the intact used sleeper in different parts, the highest content of heavy metal pollutants was recorded in the upper layer of the sleeper, i.e. in the creosote impregnated layer (for example, from 8 to $59 \mathrm{mg} / \mathrm{kg}$ for $\mathrm{Pb}$, from 0.9 to $1 \mathrm{mg} / \mathrm{kg}$ for Cd, from 26 to $59 \mathrm{mg} / \mathrm{kg}$ for $\mathrm{Zn}$ ). Creosote is derived from coal and polycyclic aromatic hydrocarbons and from phenolic and heterocyclic aromatic compounds forming integrated compounds with heavy metals.

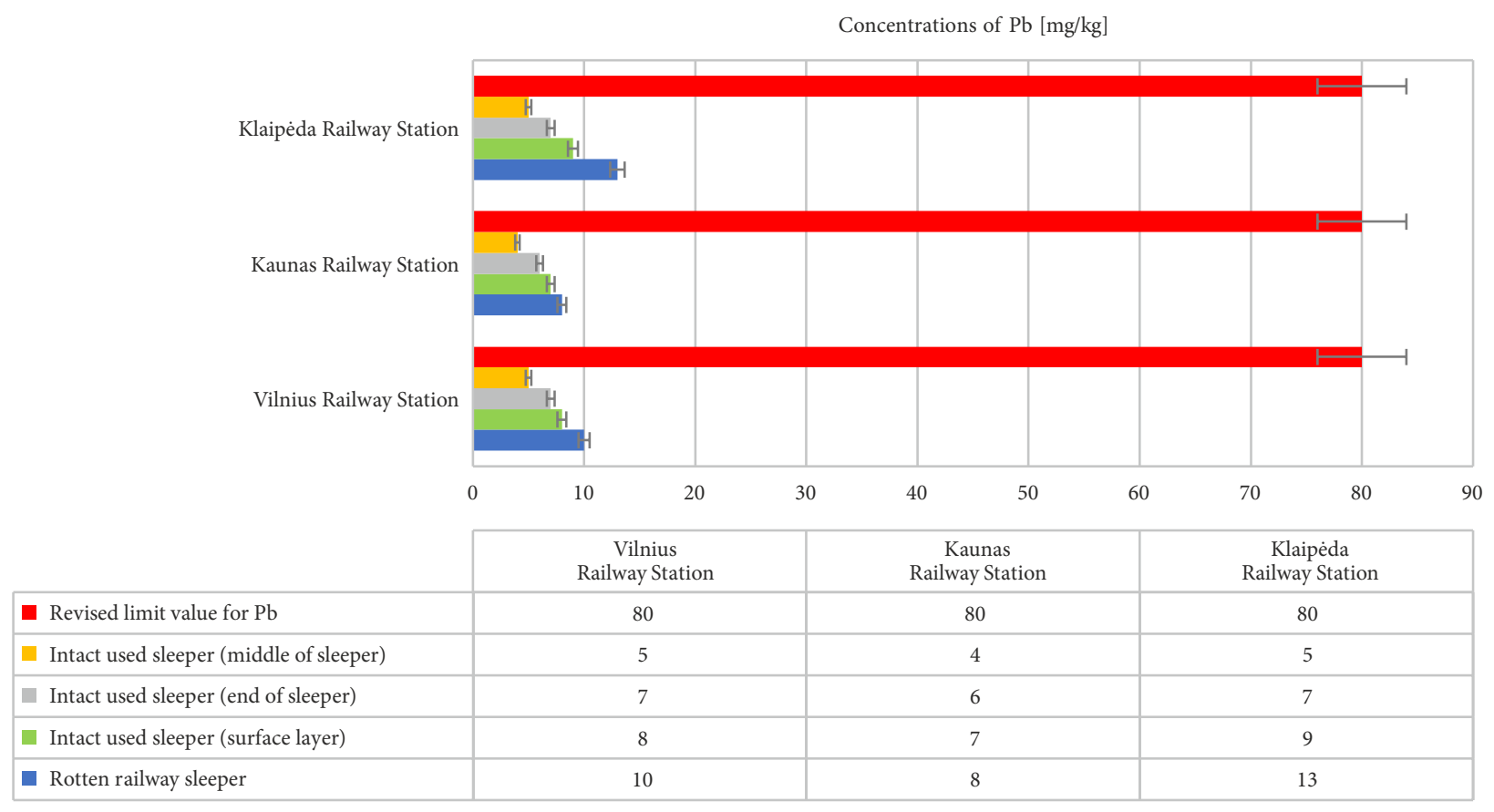

Figure 5. The distribution of the concentrations of $\mathrm{Pb}$ in the intact used and rotten wooden railway sleepers at the biggest Lithuanian railway stations (Vilnius, Kaunas and Klaipeda)

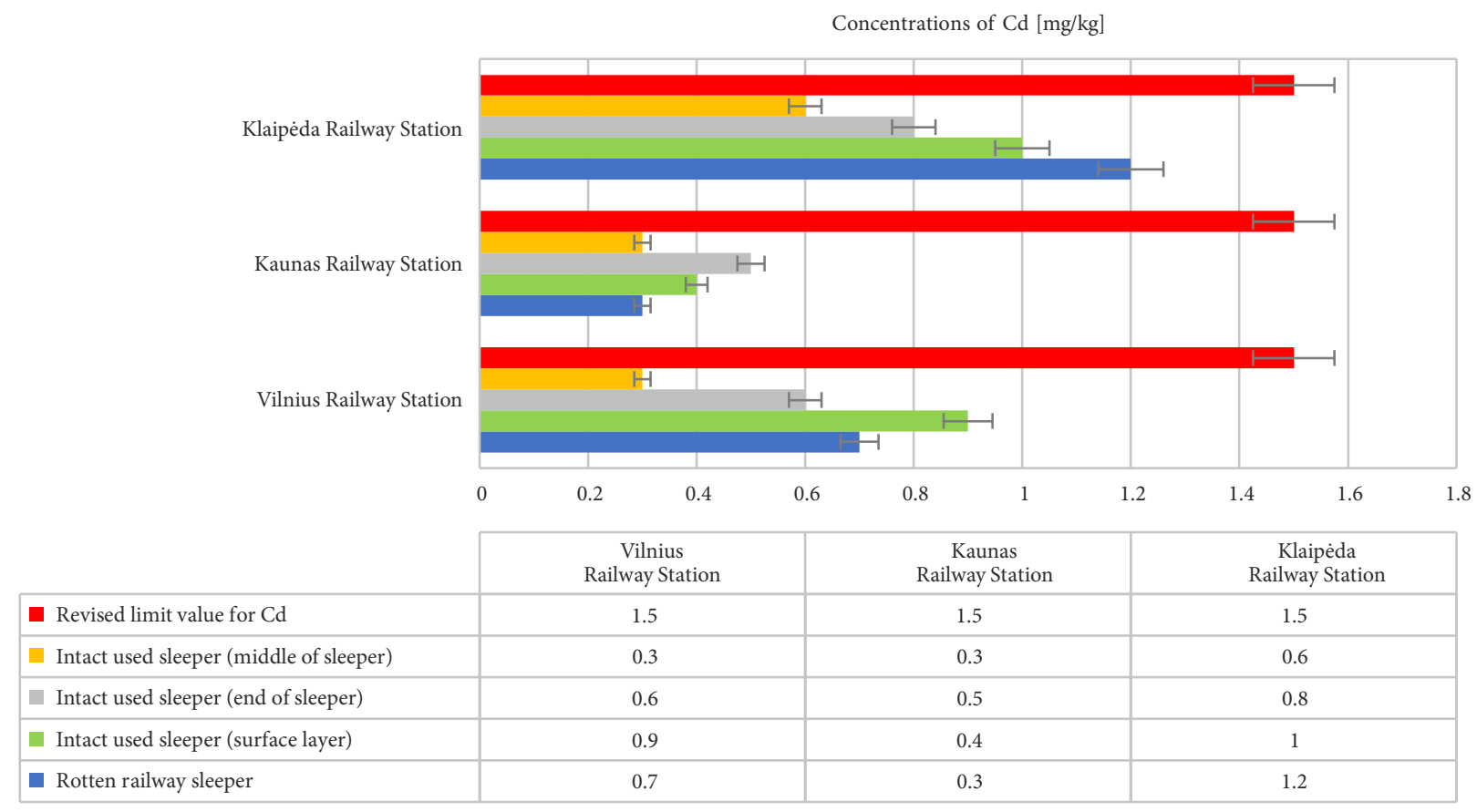

Figure 6. The distribution of the concentrations of $\mathrm{Cd}$ in the intact used and rotten wooden railway sleepers at the biggest Lithuanian railway stations (Vilnius, Kaunas and Klaipeda) 


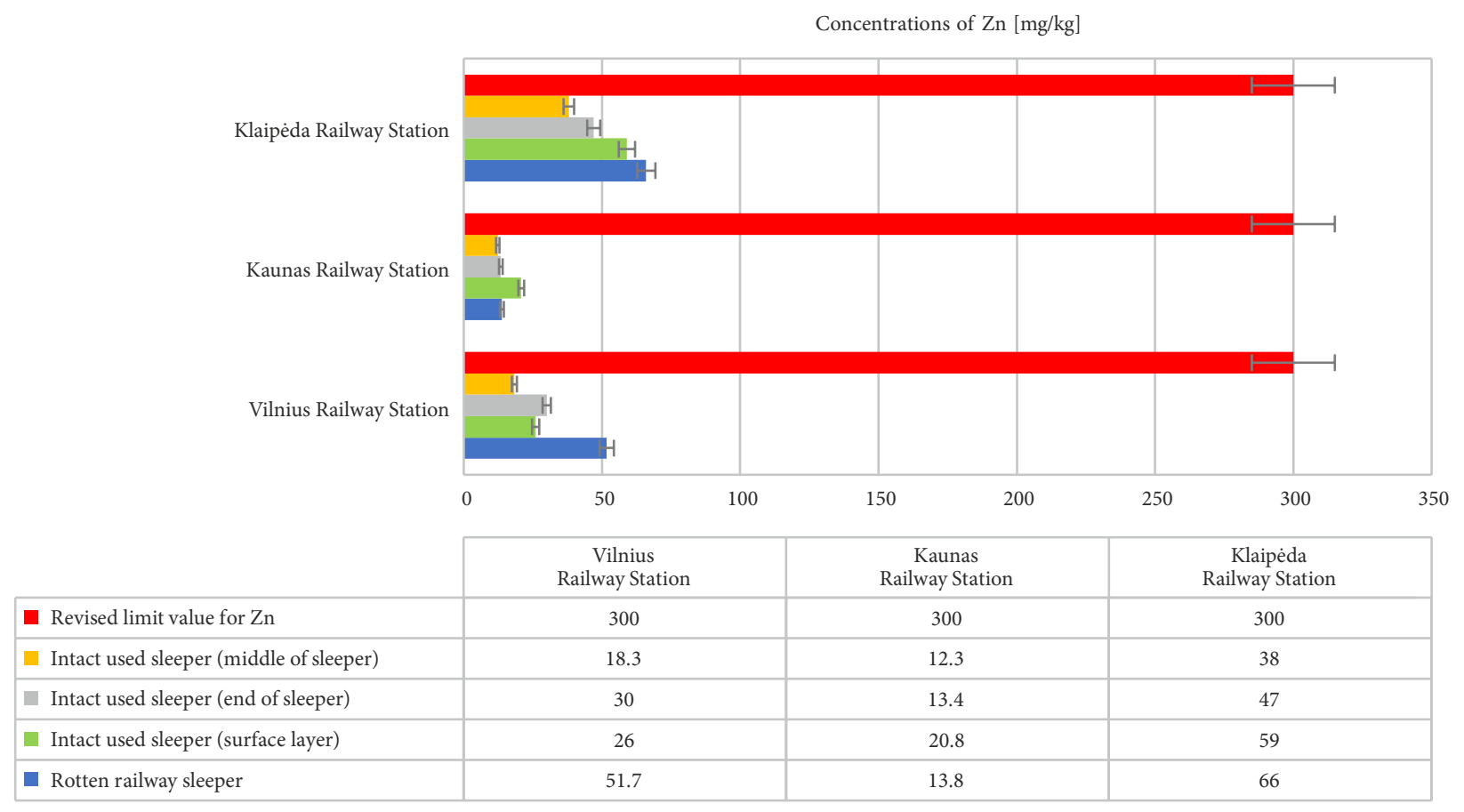

Figure 7. The distribution of the concentrations of $\mathrm{Zn}$ in the intact used and rotten wooden railway sleepers at the biggest Lithuanian railway stations (Vilnius, Kaunas and Klaipeda)

As a result, heavy metal pollution was detected in the upper layer of the intact used sleeper rather than in the other parts of it. The highest concentrations of heavy metals (especially $\mathrm{Pb}$ and $\mathrm{Zn}$ ) were found in both the intact used and rotten wooden sleepers taken from Vilnius and Klaipeda railway stations where rolling stock traffic was more intensive, loading operations were performed and traction rolling stock was stopped more frequently, which caused the friction of metals and resulted in the environmental pollution of the soil, surface and groundwater, etc. thus emitting heavy metals etc. The lowest level of pollution by heavy metals was established in the intact used and rotten wooden sleepers at Kaunas Railway Station. For example, the intact used railway sleepers contained from 4 to $7 \mathrm{mg} / \mathrm{kg}$ of $\mathrm{Pb}$, from 0.3 to $0.5 \mathrm{mg} / \mathrm{kg}$ of Cd and from 12.3 to $20.8 \mathrm{mg} / \mathrm{kg}$ of $\mathrm{Zn}\left(R^{2}=0.99\right)$. Apparently, it was influenced by lower traction stock intensity compared to other railway stations (Klaipeda and Vilnius), which was supported by the research conducted by other scientists (Shi et al. 2008; Smičiklas et al. 2015; Stojić et al. 2014; Sun et al. 2010; Száková et al. 2010; Šeda et al. 2017; Wei, Yang 2010; Zehetner et al. 2009; Zhang et al. 2012, 2013).

Summarizing the obtained results according to the methods presented in the literature, we can say, that the investigated wooden railway sleepers are the most contaminated (up to $1.2 \mathrm{mg} / \mathrm{kg}$ ) with Cd. In comparison, other researchers obtained similar research results with values from 0.35 to $1.19 \mathrm{mg} / \mathrm{kg}$. Meanwhile, in wooden railway sleepers, the highest pollution of $\mathrm{Pb}$ was only $13 \mathrm{mg} / \mathrm{kg}$. When other researchers recorded an average of three times higher contamination of $\mathrm{Pb}$ (about $34.4 \mathrm{mg} / \mathrm{kg}$ ). Analogous research results were obtained with $\mathrm{Zn}$. For example, in the investigated wooden railway sleepers, the maximum pollution of $\mathrm{Zn}$ was only up to $66 \mathrm{mg} / \mathrm{kg}$, while other researchers recorded one and a half times higher pollution of $\mathrm{Zn}$ (on average up to $85 \mathrm{mg} / \mathrm{kg}$ ). We are confident, that the investigated results will be confirmed by the further development of this study.

Consequently, in order to reduce the negative impact on the environment, creosote-impregnated sleepers should not be stored near the railway or at near railway stations (Stojic et al. 2017; Šeda et al. 2017; Zhang et al. 2012; Chen et al. 2014).

\section{Conclusions}

The highest $\mathrm{Pb}$ concentrations (up to $50 \mathrm{mg} / \mathrm{kg}$ ) were found in the upper (up to $10 \mathrm{~cm}$ ) soil layer at a distance of $5 \mathrm{~m}$ from railway sleepers at Vilnius Railway Station. As for deeper soil layers $(10 \ldots 20$ and $20 \ldots 40 \mathrm{~cm}), \mathrm{Pb}$ concentrations evenly distributed within the limits of $10 \ldots 20$ and $8 \ldots 12 \mathrm{mg} / \mathrm{kg}$ respectively. Such amounts of $\mathrm{Pb}$ were significantly influenced by the origin of soil rock, the content of organic matter in the soil and its acidity $(\mathrm{pH})$.

A comparison of the results of the investigated soil across the tested railway stations disclosed that Klaipeda Railway Station was the most polluted with Cd. The highest Cd concentrations (up to $1.5 \ldots 1.8 \mathrm{mg} / \mathrm{kg}$ ) were found in the upper (up to $10 \mathrm{~cm}$ ) soil layer at a distance of $5 \ldots 10 \mathrm{~m}$ from the railway sleepers placed in light clay loam. Due to the higher concentration of humus, clay, minerals, phosphate and carbonate ions, insoluble and inorganic $\mathrm{Cd}$ compounds formed. As for the deeper layers of the soil $(10 \ldots 20$ and $20 \ldots 40 \mathrm{~cm}), \mathrm{Cd}$ concentrations evenly distributed within the limits of $1 \ldots 1.2$ and $0.8 \ldots 0.9 \mathrm{mg} / \mathrm{kg}$ respectively. 
Among the investigated stations, the lowest level of pollution by heavy metals, including $\mathrm{Zn}$, was found at Kaunas Railway Station where sandy loams predominated. Apparently, more $\mathrm{Zn}$ may have accumulated in the upper layer due to a higher content of organic material where $\mathrm{Zn}$ was more likely to accumulate. Considering deeper soil layers $(10 \ldots 20$ and $20 \ldots 40 \mathrm{~cm})$, the concentrations of the tested pollutant evenly distributed within the limits of $50 . .70$ and $30 \ldots 50 \mathrm{mg} / \mathrm{kg}$ respectively.

A comparison of heavy metal pollutants found on the intact used and rotten wooden railway sleepers disclosed that the latter sleepers compared to the intact used ones, were more seriously polluted with heavy metals, which made from 8 to $13 \mathrm{mg} / \mathrm{kg}$ for $\mathrm{Pb}$, from 0.3 to $1.2 \mathrm{mg} / \mathrm{kg}$ for $\mathrm{Cd}$, from 13.8 to $66 \mathrm{mg} / \mathrm{kg}$ for $\mathrm{Zn}$. The rotten sleepers contained a higher content of organic compounds involved in forming complex compounds of varying durability ranging from semi-persistent to fragile.

For examining the contamination of the intact used sleeper in different parts, the highest content of heavy metal pollutants was recorded in the upper layer of the sleeper, i.e. in the creosote impregnated layer (for example, from 8 to $59 \mathrm{mg} / \mathrm{kg}$ for $\mathrm{Pb}$, from 0.9 to $1 \mathrm{mg} / \mathrm{kg}$ for $\mathrm{Cd}$, from 26 to $59 \mathrm{mg} / \mathrm{kg}$ for $\mathrm{Zn}$ ). Creosote is derived from coal and polycyclic aromatic hydrocarbons and from phenolic and heterocyclic aromatic compounds forming integrated compounds with heavy metals. As a result, heavy metal pollution was detected in the upper layer of the intact used sleeper rather than in the other parts of it.

The lowest level of pollution by heavy metals was established in the intact used and rotten wooden sleepers at Kaunas Railway Station. For example, the intact used railway sleepers contained from 4 to $7 \mathrm{mg} / \mathrm{kg}$ of $\mathrm{Pb}$, from 0.3 to $0.5 \mathrm{mg} / \mathrm{kg}$ of Cd and from 12.3 to $20.8 \mathrm{mg} / \mathrm{kg}$ of $\mathrm{Zn}\left(R^{2}=0.99\right)$. In fact, it was influenced by lower traction stock intensity compared to other railway stations (Klaipeda and Vilnius).

Studies on the distribution of heavy metals $(\mathrm{Pb}, \mathrm{Cd}$, $\mathrm{Zn}$ ) according to the new methodology have shown that railway transport can have an impact on the surrounding environment, especially in urban areas. These complex studies have shown that the safe distance from the railway stations is up to $10 \ldots 15 \mathrm{~m}$. Consequently, maintaining a safe distance from the railway in practice would reduce the negative impact of pollution on humans and the environment.

\section{Disclosure statement}

Authors do not have any competing financial, professional, or personal interests from other.

\section{References}

Bai, J.; Xiao, R.; Cui, B.; Zhang, K.; Wang, Q.; Liu, X.; Gao, H.; Huang, L. 2011. Assessment of heavy metal pollution in wetland soils from the young and old reclaimed regions in the Pearl River Estuary, South China, Environmental Pollution 159(3): 817-824. https://doi.org/10.1016/j.envpol.2010.11.004
Baumhardt, R. L.; Stewart, B. A.; Sainju, U. M. 2015. North American soil degradation: processes, practices, and mitigating strategies, Sustainability 7(3): 2936-2960.

https://doi.org/10.3390/su7032936

Blake, L.; Goulding, K. W. T. 2002. Effects of atmospheric deposition, soil $\mathrm{pH}$ and acidification on heavy metal contents in soils and vegetation of semi-natural ecosystems at Rothamsted experimental station, UK, Plant and Soil 240(2): 235-251. https://doi.org/10.1023/A:1015731530498

Blok, J. 2005. Environmental exposure of road borders to zinc, Science of the Total Environment 348(1-3): 173-190. https://doi.org/10.1016/j.scitotenv.2004.12.073

Burkhardt, M.; Rossi, L.; Boller, M. 2008. Diffuse release of environmental hazards by railways, Desalination 226(1-3): 106-113. https://doi.org/10.1016/j.desal.2007.02.102

Chen, X.; Xia, X. H.; Zhao, Y.; Zhang, P. 2010. Heavy metal concentrations in roadside soils and correlation with urban traffic in Beijing, China, Journal of Hazardous Materials 181(1-3): 640-646. https://doi.org/10.1016/j.jhazmat.2010.05.060

Chen, Z.; Wang, K. X.; Ai, Y. W.; Li, W.; Gao, H.; Fang, C. 2014. The effects of railway transportation on the enrichment of heavy metals in the artificial soil on railway cut slopes, Environmental Monitoring and Assessment 186(2): 1039-1049. https://doi.org/10.1007/s10661-013-3437-3

Christoforidis, A.; Stamatis, N. 2009. Heavy metal contamination in street dust and roadside soil along the major national road in Kavala's region, Greece, Geoderma 151(3-4): 257-263. https://doi.org/10.1016/j.geoderma.2009.04.016

Dai, J.; Becquer, T.; Rouiller, J. H.; Reversat, G.; Bernhard-Reversat, F.; Lavelle, P. 2004. Influence of heavy metals on C and N mineralisation and microbial biomass in $\mathrm{Zn}-, \mathrm{Pb}-, \mathrm{Cu}-$, and Cd-contaminated soils, Applied Soil Ecology 25(2): 99-109. https://doi.org/10.1016/j.apsoil.2003.09.003

Davis, A. P.; Shokouhian, M.; Ni, S. 2001. Loading estimates of lead, copper, cadmium, and zinc in urban runoff from specific sources, Chemosphere 44(5): 997-1009.

https://doi.org/10.1016/s0045-6535(00)00561-0

Fakayode, S. O.; Olu-Owolabi, B. I. 2003 Heavy metal contamination of roadside topsoil in Osogbo, Nigeria: its relationship to traffic density and proximity to highways, Environmental Geology 44(2): 150-157.

https://doi.org/10.1007/s00254-002-0739-0

Fonseca, B.; Figueiredo, H.; Rodrigues, J.; Queiroz, A.; Tavares, T. 2011. Mobility of $\mathrm{Cr}, \mathrm{Pb}, \mathrm{Cd}, \mathrm{Cu}$ and $\mathrm{Zn}$ in a loamy sand soil: a comparative study, Geoderma 164(3-4): 232-237. https://doi.org/10.1016/j.geoderma.2011.06.016

Guo, G.; Wu, F.; Xie, F.; Zhang, R. 2012. Spatial distribution and pollution assessment of heavy metals in urban soils from southwest China, Journal of Environmental Sciences 24(3): 410-418. https://doi.org/10.1016/s1001-0742(11)60762-6

Hasselbach, L.; Ver Hoef, J. M.; Ford, J.; Neitlich, P.; Crecelius, E.; Berryman, S.; Wolk, B.; Bohle, T. 2005. Spatial patterns of cadmium and lead deposition on and adjacent to national park service lands in the vicinity of Red Dog Mine, Alaska, Science of the Total Environment 348(1-3): 211-300. https://doi.org/10.1016/j.scitotenv.2004.12.084

Helmreich, B.; Hilliges, R.; Schriewer, A.; Horn, H. 2010. Runoff pollutants of a highly trafficked urban road - correlation analysis and seasonal influences, Chemosphere 80(9): 991997. https://doi.org/10.1016/j.chemosphere.2010.05.037

HN 60:2015. Pavojinguju cheminiu medžiagu ribinès vertes dirvožemyje. Lietuvos higienos norma. Lietuvos Respublikos sveikatos apsaugos ministerija. (in Lithuanian). 
Ho, Y. B.; Tai, K. M. 1988. Elevated levels of lead and other metals in roadside soil and grass and their use to monitor aerial metal depositions in Hong Kong, Environmental Pollution 49(1): 37-51. https://doi.org/10.1016/0269-7491(88)90012-7

Huang, B.; Kuo, S., Bembenek, R. 2004. Availability of cadmium in some phosphorus fertilizers to field-grown lettuce, Water, Air, \& Soil Pollution: an International Journal of Environmental Pollution 158(1): 37-51.

https://doi.org/10.1023/B:WATE.0000044832.04770.41

Khan, M. N.; Wasim, A. A.; Sarwar, A.; Rasheed, M. F. 2011a. Assessment of heavy metal toxicants in the roadside soil along the N-5, national highway, Pakistan, Environmental Monitoring and Assessment 182(1-4): 587-595. https://doi.org/10.1007/s10661-011-1899-8

Khan, S.; Khan, M. A.; Rehman, S. 2011b. Lead and cadmium contamination of different roadside soils and plants in Peshawar City, Pakistan, Pedosphere 21(3): 351-357. https://doi.org/10.1016/S1002-0160(11)60135-5

Kim, K.-H.; Kim, S.-H. 1999. Heavy metal pollution of agricultural soils in central regions of Korea, Water, Air, \& Soil Pollution: an International Journal of Environmental Pollution 111(1-4): 109-122. https://doi.org/10.1023/A:1005056310428

Kluge, B.; Wessolek, G. 2012. Heavy metal pattern and solute concentration in soils along the oldest highway of the world the AVUS Autobahn, Environmental Monitoring and Assessment 184(11): 6469-6481.

https://doi.org/10.1007/s10661-011-2433-8

Koeleman, M.; Vd Laak, W. J.; Ietswaart, H. 1999. Dispersion of $\mathrm{PAH}$ and heavy metals along motorways in the Netherlands an overview, Science of the Total Environment 235(1-3): 347349. https://doi.org/10.1016/s0048-9697(99)00253-3

Langmi, H. W.; Watt, J. 2003. Evaluation of computer-controlled SEM in the study of metal-contaminated soils, Mineralogical Magazine 67(2): 219-231.

https://doi.org/10.1180/0026461036720096

Li, F.-R.; Kang, L.-F.; Gao, X.-Q.; Hua, W.; Yang, F.-W.; Hei, W.-L. 2007. Traffic-related heavy metal accumulation in soils and plants in Northwest China, Soil and Sediment Contamination: an International Journal 16(5): 473-484.

https://doi.org/10.1080/15320380701490168

Lee, S.-H.; Kim, E.-Y.; Hyun, S.; Kim, J.-G. 2009. Metal availability in heavy metal-contaminated open burning and open detonation soil: assessment using soil enzymes, earthworms, and chemical extractions, Journal of Hazardous Materials 170(1): 382-388. https://doi.org/10.1016/j.jhazmat.2009.04.088

Liu, H.; Chen, L.-P.; Ai, Y.-W.; Yang, X.; Yu, Y.-H.; Zuo, Y.-B.; Fu, G.-Y. 2009. Heavy metal contamination in soil alongside mountain railway in Sichuan, China, Environmental Monitoring and Assessment 152(1-4): 25-33.

https://doi.org/10.1007/s10661-008-0293-7

Lorenzo, R.; Kaegi, R.; Gehrig, R.; Grobéty, B. 2006. Particle emissions of a railway line determined by detailed single particle analysis, Atmospheric Environment 40(40): 7831-7841. https://doi.org/10.1016/j.atmosenv.2006.07.026

LST ISO 10381-1:2005. Dirvožemio kokybé. Ėminiu émimas. 1 dalis. Eminių émimo programu sudarymo vadovas (in Lithuanian).

LST ISO 10381-2:2005. Dirvožemio kokybè. Ėminiu émimas. 2 dalis. Émimo būdų vadovas (in Lithuanian).

LST ISO 10381-3:2003. Dirvožemio kokybé. Éminių émimas. 3 dalis. Saugos vadovas (in Lithuanian).

LST ISO 10381-4:2006. Dirvožemio kokybè. Ėminiu èmimas. 4 dalis. Natūralių, pusiau natūralių ir dirbamų sklypų tyrimo vadovas (in Lithuanian).
LST ISO 10381-5:2007. Dirvožemio kokybè. Ėminiu émimas. 5 dalis. Miesto ir pramoniniu sklypu dirvožemio taršos tyrimo vadovas (in Lithuanian).

LST CEN/TS 16172:2013. Dumblas, apdorotos bioatliekos ir dirvožemis. Elementu nustatymas atominès absorbcines spektrometrijos grafitineje krosneleje (GF-AAS) metodu (in Lithuanian).

LST CEN/TS 16188:2012. Dumblas, apdorotos bioatliekos ir dirvožemis. Karališkajame vandenyje ir nitrato rūgštyje tirpiu elementu nustatymas. Liepsnos atomines absorbcines spektrometrijos (LAAS) metodas (in Lithuanian).

Ma, J.-H.; Chu, C.-J.; Li, J.; Song, B. 2009. Heavy metal pollution in soils on railroad side of Zhengzhou-Putian section of Longxi-Haizhou railroad, China, Pedosphere 19(1): 121-128. https://doi.org/10.1016/S1002-0160(08)60091-0

Malawska, M.; Wiołkomirski, B. 2001. An analysis of soil and plant (taraxacum officinale) contamination with heavy metals and polycyclic aromatic hydrocarbons (PAHs) in the area of the railway junction Iława Główna, Poland, Water, Air, \& Soil Pollution: an International Journal of Environmental Pollution 127(1-4): 339-349. https://doi.org/10.1023/A:1005236016074

Morra, P.; Lisi, R.; Spadoni, G.; Maschio, G. 2009. The assessment of human health impact caused by industrial and civil activities in the Pace Valley of Messina, Science of the Total Environment 407(12): 3712-3720.

https://doi.org/10.1016/j.scitotenv.2009.03.005

Nabulo, G.; Oryem-Origa, H.; Diamond, M. 2006. Assessment of lead, cadmium, and zinc contamination of roadside soils, surface films, and vegetables in Kampala City, Uganda, Environmental Research 101(1): 42-52.

https://doi.org/10.1016/j.envres.2005.12.016

Norrström, A. C. 2005. Metal mobility by de-icing salt from an infiltration trench for highway runoff, Applied Geochemistry 20(10): 1907-1919.

https://doi.org/10.1016/j.apgeochem.2005.06.002

Olajire, A. A.; Ayodele, E. T. 1997. Contamination of roadside soil and grass with heavy metals, Environment International 23(1): 91-101. https://doi.org/10.1016/S0160-4120(96)00080-3

Pagotto, C.; Rémy, N.; Legret, M.; Le Cloirec, P. 2001. Heavy metal pollution of road dust and roadside soil near a major rural highway, Environmental Technology 22(3): 307-319.

https://doi.org/10.1080/09593332208618280

Paschke, M. W.; DeLeo, C.; Redente, E. F. 2000. Revegetation of roadcut slopes in Mesa Verde national park, U.S.A., Restoration Ecology 8(3): 276-282.

https://doi.org/10.1046/j.1526-100x.2000.80039.x

Plakhotnik, V. N.; Onyshchenko, J. V.; Yaryshkina, L. A. 2005. The environmental impacts of railway transportation in the Ukraine, Transportation Research Part D: Transport and Environment 10(3): 263-268. https://doi.org/10.1016/j.trd.2005.02.001

Saeedi, M.; Hosseinzadeh, M.; Jamshidi, A.; Pajooheshfar, S. P. 2009. Assessment of heavy metals contamination and leaching characteristics in highway side soils, Iran, Environmental Monitoring and Assessment 151(1-4): 231-241.

https://doi.org/10.1007/s10661-008-0264-Z

Saeedi, M.; Li, L. Y.; Salmanzadeh, M. 2012. Heavy metals and polycyclic aromatic hydrocarbons: Pollution and ecological risk assessment in street dust of Tehran, Journal of Hazardous Materials 227-228: 9-17. https://doi.org/10.1016/j.jhazmat.2012.04.047

Sansalone, J. J.; Buchberger, S. G. 1997. Partitioning and first flush of metals in urban roadway storm water, Journal of Environmental Engineering 123(2): 134-143. https://doi.org/10.1061/(ASCE)0733-9372(1997)123:2(134) 
Sezgin, N.; Ozcan, H. K.; Demir, G.; Nemlioglu, S.; Bayat, C. 2004. Determination of heavy metal concentrations in street dusts in Istanbul E-5 highway, Environment International 29(7): 979-985. https://doi.org/10.1016/S0160-4120(03)00075-8

Shi, G.; Chen, Z.; Xu, S.; Zhang, J.; Wang, L.; Bi, C.; Teng, J. 2008. Potentially toxic metal contamination of urban soils and roadside dust in Shanghai, China, Environmental Pollution 156(2): 251-260. https://doi.org/10.1016/j.envpol.2008.02.027

Smičiklas, I.; Jović, M.; Šljivić-Ivanović, M.; Mrvić, V.; Čakmak, D.; Dimović, S. 2015. Correlation of $\mathrm{Sr}^{2+}$ retention and distribution with properties of different soil types, Geoderma 253-254: 21-29.

https://doi.org/10.1016/j.geoderma.2015.04.003

Stojić, N.; Pucarević, M.; Mrkajić, D.; Kecojević, I. 2014. Transformers as a potential for soil contamination, Metalurgija 53(4): 689-692.

Stojic, N.; Pucarevic, M.; Stojic, G. 2017. Railway transportation as a source of soil pollution, Transportation Research Part D: Transport and Environment 57: 124-129. https://doi.org/10.1016/j.trd.2017.09.024

Sun, Y.; Zhou, Q.; Xie, X.; Liu, R. 2010. Spatial, sources and risk assessment of heavy metal contamination of urban soils in typical regions of Shenyang, China, Journal of Hazardous Materials 174(1-3): 455-462. https://doi.org/10.1016/j.jhazmat.2009.09.074

Száková, J.; Miholová, D.; Tlustoš, P.; Šestáková, I.; Frková, Z. 2010. Effect of soil properties and sample preparation on extractable and soluble $\mathrm{Pb}$ and $\mathrm{Cd}$ fractions in soils, Agricultural Sciences 1(3): 119-130. https://doi.org/10.4236/as.2010.13015

Šeda, M.; Śíma, J.; Volavka, T.; Vondruška, J. 2017. Contamination of soils with $\mathrm{Cu}, \mathrm{Na}$ and $\mathrm{Hg}$ due to the highway and railway transport, Eurasian Journal of Soil Science 6(1): 59-64. https://doi.org/10.18393/ejss.284266

Tromp, K.; Lima, A. T.; Barendregt, A.; Verhoeven, J. T. A. 2012. Retention of heavy metals and poly-aromatic hydrocarbons from road water in a constructed wetland and the effect of de-icing, Journal of Hazardous Materials 203-204: 290-298. https://doi.org/10.1016/j.jhazmat.2011.12.024

Vilniškis, R.; Vaiškūnaite, R. 2018. Complex contamination research and hazard assessment of the waste of the wooden railway sleeper, Baltic Journal of Road and Bridge Engineering 13(4): 385-403. https://doi.org/10.7250/bjrbe.2018-13.424

Vitaliano, D. F. 1992. An economic assessment of the social costs of highway salting and the efficiency of substituting a new deicing material, Journal of Policy Analysis and Management 11(3): 397-418. https://doi.org/10.2307/3325069

Wei, B.; Yang, L. 2010. A review of heavy metal contaminations in urban soils, urban road dusts and agricultural soils from China, Microchemical Journal 94(2): 99-107. https://doi.org/10.1016/j.microc.2009.09.014

Wierzbicka, M.; Bemowska-Kałabun, O.; Gworek, B. 2015. Multidimensional evaluation of soil pollution from railway tracks, Ecotoxicology 24(4): 805-822. https://doi.org/10.1007/s10646-015-1426-8

Wiłkomirski, B.; Galera, H.; Sudnik-Wójcikowska, B.; Staszewski, T.; Malawska, M. 2012. Railway tracks - habitat conditions, contamination, floristic settlement - a review, Environment and Natural Resources Research 2(1): 86-95. https://doi.org/10.5539/enrr.v2n1p86

Wiłkomirski, B.; Sudnik-Wójcikowska, B.; Galera, H.; Wierzbicka, M.; Malawska, M. 2011. Railway transportation as a serious source of organic and inorganic pollution, Water, Air, \& Soil Pollution: an International Journal of Environmental Pollution 218 (1-4): 333-345.

https://doi.org/10.1007/s11270-010-0645-0
Zehetner, F; Rosenfellner, U.; Mentler, A.; Gerzabek, M. H. 2009. Distribution of road salt residues, heavy metals and polycyclic aromatic hydrocarbons across a highway-forest interface, Water, Air, \& Soil Pollution: an International Journal of Environmental Pollution 198(1-4): 125-132. https://doi.org/10.1007/s11270-008-9831-8

Zhang, H.; Wang, Z.; Zhang, Y.; Hu, Z. 2012. The effects of the Qinghai-Tibet railway on heavy metals enrichment in soils, Science of the Total Environment 439: 240-248. https://doi.org/10.1016/j.scitotenv.2012.09.027

Zhang, H.; Zhang, Y.; Wang, Z.; Ding, M. 2013. Heavy metal enrichment in the soil along the Delhi-Ulan section of the Qinghai-Tibet railway in China, Environmental Monitoring and Assessment 185(7): 5435-5447. https://doi.org/10.1007/s10661-012-2957-6 